\title{
Evaluating Edaphic Conditions Favoring Reed Canary Grass Invasion in a Restored Native Prairie
}

\author{
Cynthia A. Stiles, Brynn Bemis and Joy B. Zedler
}

\begin{abstract}
Curtis Prairie, renowned as the world's earliest ecological restoration site, was invaded by reed canary grass (Phalaris arundinacea) after urban stormwater inflows cut a creek and inundated a $2000-\mathrm{m}^{2}$ floodplain. We evaluated the edaphic conditions directly downstream from a stormwater retention pond to determine if sedimentation, nutrients, or elevated groundwater might have favored growth of this wetland weed. A definite signature of urban stormwater influence on reed canary grass expansion is strongly indicated by enriched nutrients (bioavailable phosphorus, nitrate-nitrogen), salt (sodium), and metals (copper and zinc), each of which was significantly elevated in the invasion area and downstream in a sedge meadow. Sodium could have dispersed clays and reduced the soil's infiltration capacity, thereby impounding water. We evaluated soil and hydrologic conditions in order to develop a conceptual model of the invasion process in Curtis Prairie. We suggest that 1 ) stormwater outflow from the retention pond initiated erosion; 2) reed canary grass established alongside the eroded creek and expanded vegetatively into the prairie as native plants succumbed to flooding; 3) contaminants were continuously delivered onto the floodplain, degrading soil structure and promoting aggressive growth of reed canary grass; and 4) fine-grained sediments and organic matter were transported downstream to the sedge meadow, possibly contributing to future reed canary grass expansion into this area.
\end{abstract}

Keywords: edaphic conditions, reed canary grass (Phalaris arundinacea), stormwater, urbanization

R estoring landscapes is difficult where the impacts of urbanization favor invasive species. Even established restored sites are vulnerable to invasion, especially where environmental conditions have been permanently altered (Mack et al. 2000, Zedler and Kercher 2004). Changes associated with urbanization, including artificial drainage, paved surfaces, the creation of retention ponds for stormwater run-off, and other hydrologic redirectors, alter the soil-waterplant interface and strongly influence plant communities. When soils are disturbed, structure is often degraded and hydrology is disrupted (Caron et al. 1996), often leading to redistribution of physical and biogeochemical

Ecological Restoration Vol. 26, No. 1, 2008 ISSN 1522-4740 E-ISSN 1543-4079 (C)2008 by the Board of Regents of the University of Wisconsin System. components through erosion, deposition, and nutrient enrichment.

In the Midwest, reed canary grass (Phalaris arundinacea, hereafter RCG) often takes advantage of soil and hydrologic conditions that have been altered by urban run-off (Galatowitsch et al. 1999, Lindig-Cisneros and Zedler 2002a, Kercher et al. 2004). This cool-season, clonal perennial has been widely introduced for animal forage and streambank stabilization. It has successfully encroached on native grass communities in many settings and over thousands of hectares, including in urban areas. In restored wetlands, it has been found to readily outgrow native vegetation and form monospecific stands, with a general loss of plant, insect, and structural diversity (Kercher et al. 2004). Three primary soil and water factors influence the growth of RCG (Lavergne and Molofsky 2004, Kercher et al.
2006): 1) presence and intensity of physical disturbance; 2) hydrologic regime; and 3) nutrient status. Areas subjected to physical disturbance, such as erosion or sediment accumulation, are vulnerable to invasion where canopy gaps provide the opportunity for RCG to establish a clone, which can then expand vegetatively (LindigCisneros and Zedler 2002a, 2002b, Maurer and Zedler 2002). Likewise, flooding can create canopy gaps by killing intolerant species while promoting RCG growth, as this species tolerates poorly drained soils (Morrison and Molofsky 1998, Miller and Zedler 2003). Nutrient enrichment also enhances RCG expansion and competitive dominance (Green and Galatowitsch 2002, Maurer and Zedler 2002). 


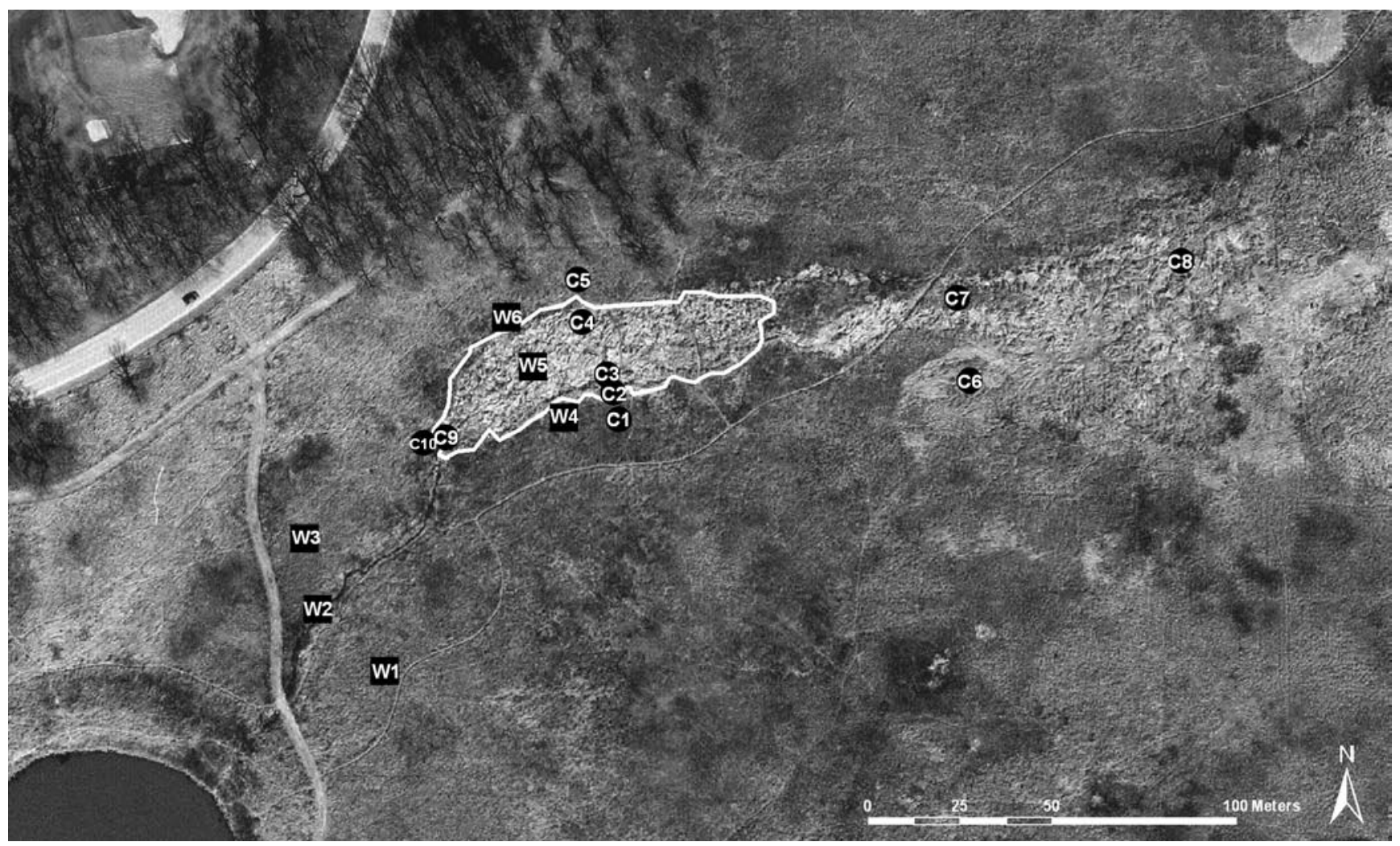

Figure 1. An aerial view of the study area in the restored Curtis Prairie at the University of Wisconsin Arboretum indicating locations of wells (W) and soil cores (C). The stormwater retention pond is visible in the lower left corner. The pond connects via an outflow channel to the RCG invasion area, outlined in white. The sedge meadow lies downslope, just east of the invaded area. Arboretum Drive is visible in the upper left corner. A much more heavily traveled highway lies within 200 meters of the area, to the south of the photo.

\section{Research Objectives}

Curtis Prairie in the University of Wisconsin-Madison Arboretum is renowned as the oldest restored prairie in the world. The 29-ha site, once farmland, was restored during the 1930s to a mixed tallgrass and forb moist prairie community. According to a 2003 survey (Snyder 2004), however, RCG has invaded, and a dense, monotypic stand of the plant now covers over 15 percent of the prairie. Our primary goal for this study was to identify edaphic conditions that might explain this distribution of RCG within Curtis Prairie and predict any future expansion.

We hypothesized that the RCG stand coincides with the area most strongly influenced by urban stormwater, which is known to stimulate expansion of RCG (Kercher et al. 2007). We used field and laboratory tools to detect a 30-year "signature" of stormwater effects on the soil and hydrology of Curtis Prairie within and outside the RCG stand, the time that has lapsed since the installation of the original detention pond and the present. We established monitoringwell transects across a stormwater pond outflow stream, both outside and within the RCG stand to assess the dominant surface water and soil hydrologic processes that may be affecting the invasion. We also took soil cores from within the RCG stand and from the surrounding restored prairie, and evaluated the biogeochemical and physical characteristics of the soils. Our goal was to identify significant differences between the RCG monotype and the surrounding area, in order to predict future expansion and suggest ways to control the invasion, such as containing stormwater sediments or contaminants.

\section{Study Site History}

Curtis Prairie experiences a temperate, subhumid climate with a mean annual temperature of $10^{\circ} \mathrm{C}$ with mean seasonal range from $-8^{\circ} \mathrm{C}$ in winter to $25.6^{\circ} \mathrm{C}$ in summer. Mean annual precipitation is $840 \mathrm{~mm}$ and occurs mainly as rainfall in the spring and summer (WISCO 2007). Before restoration, much of this area was plowed, then used as pasture or hay meadow. Restoration began as experimental plantings in 1935 , under the leadership of Norman Fassett with help from his students and the Civilian Conservation Corps; in 1936, Theodore Sperry planted more extensively and John Curtis directed several research efforts (Sachse 1974, Blewett and Cottam 1984, Cochrane et al. 2006). Before being restored to prairie, our study site (Figure 1) was farmed for corn and then turned into pasture (Cochrane et al. 2006). Extensive soil erosion of the uplands 
and burial of organic rich lowland (wetland) soils were attributed to agricultural practices (Curtis 1951).

By the mid 1970s, urbanization had replaced agriculture as the main source of disturbance. This former farmland, now restored prairie, lies surrounded by residential and industrial developments and bounded by heavily traveled roadways. The resultant redirection of runoff has altered both the chemistry and the physical characteristics of the soil-water system. Significantly, a stormwater retention pond (Curtis Pond) was built in the southwest corner of the prairie to slow water flows from the urban watershed and to settle suspended solids prior to overland flow across the prairie. After the pond was built in the 1970s, surface flows cut a $1-\mathrm{m}$ wide stream eastward toward a sedge meadow. RCG first appeared along that stream ( $R$. Henderson, WDNR, pers. comm.) and apparently spread vegetatively, forming a dense monotypic stand. In the latest monitoring survey of Curtis Prairie, RCG occurred in 16\% of about 970 sample points (Snyder 2004). The RCG invasion area is periodically inundated during spring snowmelt and also during summer storm events (D. Zaber, UW Arboretum, pers. comm.). Downstream from the RCG stand the drainage pattern becomes more diffuse, soils are poorly drained, and tussock sedge (Carex stricta) dominates the wet meadow.

\section{Methods}

To locate the signature of stormwater influence on Curtis Prairie we compared soils in three plant communities: the restored prairie (RP), the RCG monotype, and the downstream sedge meadow (SM) (Figure 1). Curtis Prairie has subtle variations in microtopography, with relief differences not exceeding $2 \mathrm{~m}$. Generally, the land slopes gently to the east-northeast from the upland native prairie into the wet sedge meadow. The incised outflow streambed cuts down about $1 \mathrm{~m}$ below the mean elevation of the prairie. Water flows downstream from the restored prairie, through the RCG stand and into the sedge meadow. Streamflow is typically constant throughout the summer, becoming intermittent in late summer and early autumn, usually the driest part of the growing season.

To locate sites for wells and soil cores, we used a high-resolution $(3 \mathrm{~m})$ digital elevation map based on a Leica GPS 530 differential global positioning system. We positioned six water table wells along two transects, one that ran through the RCG stand and another across restored prairie (Figure 1). The wells were constructed of PVC pipes with an inner diameter of 57 $\mathrm{mm}$ fitted at the bottom with slotted screens with aperture of $0.25 \mathrm{~mm}$ (MonoFlex, Inc., Prairie du Sac, WI). We installed them on November 14, 2005, using a Giddings hydraulic probe (Giddings Machine Co., Windsor, CO). We stored the top meter of the well hole in clear $5-\mathrm{cm}$ polyurethane tubing capped on either end for later physical and biogeochemical analysis and drilled the remaining depth with a screw auger fitted to the probe apparatus. We used pure sand to fill openings around the wells and sealed the upper 10 to $15 \mathrm{~cm}$ of each with chips of bentonite clay to prevent surface contamination (Sanders 1998). Total lengths of the wells ranged from 4.54 to $6.23 \mathrm{~m}$. We measured water table heights by hand with a measuring tape and audio-indicator five times between January 8 and June 30, 2006.

In addition to the wells, soil samples were taken from 10 locations in the study area (Figure 1). Five cores were taken in the RCG stand, three in the SM, and two in the RP. At each location we collected samples down to $1 \mathrm{~m}$ using a $7.5-\mathrm{cm}$ diameter bucket auger, separated at regular intervals $(5,10$, $20,40,60$, and $100 \mathrm{~cm}$ ) during the coring process. Additionally, we took a second set of samples from the upper meter of soil extracted while drilling the wells. All samples were returned to the laboratory, described for physical characteristics such as color, texture, and structure following methods prescribed by the USDA-NRCS Soil Survey (Schoenberger et al. 2002), and prepared for analysis by drying and grinding either by hand with a mortar and pestle or with a mechanical grinder. The extracted cores from the wells were extruded, described, and sectioned into $2-\mathrm{cm}$ intervals before being air dried and ground.

Soils were analyzed in the UW Soil Science Department and at the Soil and Plant Analysis Laboratory (Madison, WI). As a proxy for infiltration and to determine pattern of sedimentation, we evaluated particle size distribution using the pipette method, which has relatively high sensitivity for fine-grained sediments (Gee and Bauder 1996). Biogeochemical parameters evaluated included: $\mathrm{pH}$ (Thomas 1986); total nitrogen (N) and carbon (C) by infrared spectroscopy (LECO model 2000 CNS, LECO Corp., St. Joseph, MI) (Yeomans and Bremner 1991, Nelson and Sommers 1996); ammonium $\left(\mathrm{NH}_{4}\right)-\mathrm{N}$ and nitrate $\left(\mathrm{NO}_{3}\right)-\mathrm{N}$ by potassium chloride extraction and flow injection on a Lachat QuickChem 8000 Flow Injection Analyzer (Lachat Instruments, Loveland, CO); bioavailable phosphorus by mild acid extraction and colorimetric analysis (Bray and Kurtz 1945); and trace/heavy metals by acid digestion/ICP analysis (method adapted from Olson and Summers 1982). Statistical evaluations (Student's $t$-test and one-way ANOVA) used SigmaPlot version 9.0 (SYSTAT Software, Inc., Richmond, CA) and Quattro Pro version X3 (Corel Corp., Ottawa, ON, Canada). Data for this study can be found at http:// www. wisc.edu/wisconsinpress/journals/ journals/er_suppl.html.

\section{Results}

\section{Soil profiles}

Soil core stratigraphy at all locations showed relatively weak development of soil horizons, with thick dark 
epipedons (topsoil) noted especially in the RCG stand. A clay-enriched layer $10-15 \mathrm{~cm}$ thick was noted in the RP soils at 70-80 $\mathrm{cm}$ depth where the soil interfaced with the glacial till, which tended to have stones mixed into a sandy matrix. Counter to expectation, the RCG stand lacked buried surface horizons, which are typical in areas dominated by erosion processes (recent accumulations and depositions). The SM cores had similar organic-rich materials to depth and were lacking easily defined stratigraphic differentiation.

\section{Hydrology}

We obtained water table data from wells installed in fall of 2005 and monitored for the first four months of 2006. Wells 1 through 4 were slightly deeper, and remained open throughout the winter, while wells 5 and 6 froze and did not provide data (Figure 2). After the spring thaw in 2006, we found that wells 5 and 6 (within the RCG stand) had filled with fine grained sediment $(<0.25 \mathrm{~mm})$, which restricted flow and contributed to the freezing of the wells. The elevation trends indicate that the water table below the RCG stand slopes to the northeast toward Lake Wingra, a known area of groundwater discharge (USGS 1975). The water table was generally $3.6 \mathrm{~m}$ below the surface at all times during our observation. These depths are far below the rooting depth of most grasses and forbs. Thus, surface flow dynamics, not groundwater flow or upwelling, appear to be the more important hydrologic component during periods of spring and summer flooding.

\section{Soil texture}

Textural distributions of sand, silt, and clay (Figure 3 ) were very similar among the three communities, and typical of soils in this area (Hole 1976). The $\mathrm{RP}$ and SM soil textures (Figures 3A and $3 \mathrm{C}$, respectively) fall within distinguishable textural fields, and are significantly different through profile interval means $(p<0.04)$. The particle

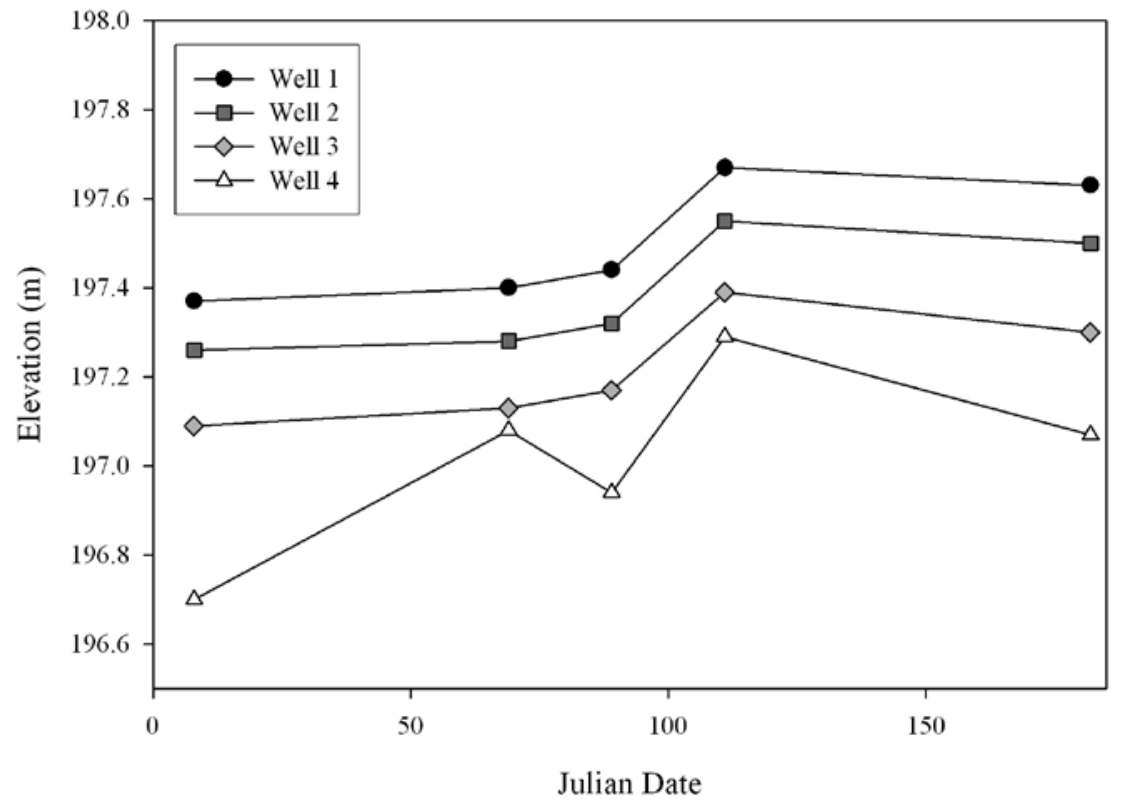

Figure 2. Groundwater table elevations monitored in 2005. The water table was 2.81 to $4.53 \mathrm{~m}$ below the surface at all times during our observation period. Mean surface elevation above sea level (not shown) is $200.6 \mathrm{~m}$.

distribution of soils in the RCG (Figure 3B) was significantly different through profile interval means $(p<0.01)$, but not significantly different from SM particle distributions. The coarsest textures occur in the RCG soils, particularly at depth, where up to $77 \%$ by weight is sand. Generally, the soils surrounding the immediate Lake Wingra basin are underlain by a fine-grained sandy outwash mixed with glacial till that dominates groundwater movement and is separated from the soils by a thin clay-rich layer (Stiles, unpub. data). Although thin $(<15 \mathrm{~cm})$, this layer plays a significant role in the dynamics of surface, vadose (sub-soil), and ground water chemistry. Statistical analysis (paired $t$-test) of particle distributions at depth intervals showed no significant difference between the RP and RCG silt and sand contents, but silt and sand contents of the SM area were significantly different from both RP and RCG paired depths (Figure 3).

\section{Biogeochemistry}

The reaction (measured as $\mathrm{pH}$ ) of the soils taken from the three communities was relatively similar through depth. There were no significant differences between the mean distilled water $\mathrm{pH}$ values for the three communities regardless of depth. However, the mean $\mathrm{CaCl}_{2} \mathrm{pH}$ values for the $\mathrm{RP}$ (5.95) and the SM (6.37) differed significantly $(p<0.005)$. This $\mathrm{pH}$ value was a general proxy for exchangeable acidity in the soils, and the greater the difference between this value and corresponding distilled-water $\mathrm{pH}$ values indicates that the exchange complex of the soil holds either more aluminum or more hydronium $\left(\mathrm{H}^{+}\right)$ions. In general, the RP had highest exchangeable acidity, decreasing into the SM.

Carbon and nitrogen, two major constituents of organic matter, showed some differences in depth distributions among communities. Total carbon (Figure 4) in the soils of all locations occurs primarily as organic $\mathrm{C}$ in the upper $50 \mathrm{~cm}$ of the soil. Profile mean differences in $\mathrm{C}$ content were significant only between RP vs. SM and RCG vs. SM. The wetter conditions of the SM have promoted organic matter preservation, so values for total carbon are much higher than those found in the other two communities. In addition, the buried surfaces noted in the cores coincided with a general increase in total carbon at around $40 \mathrm{~cm}$. 


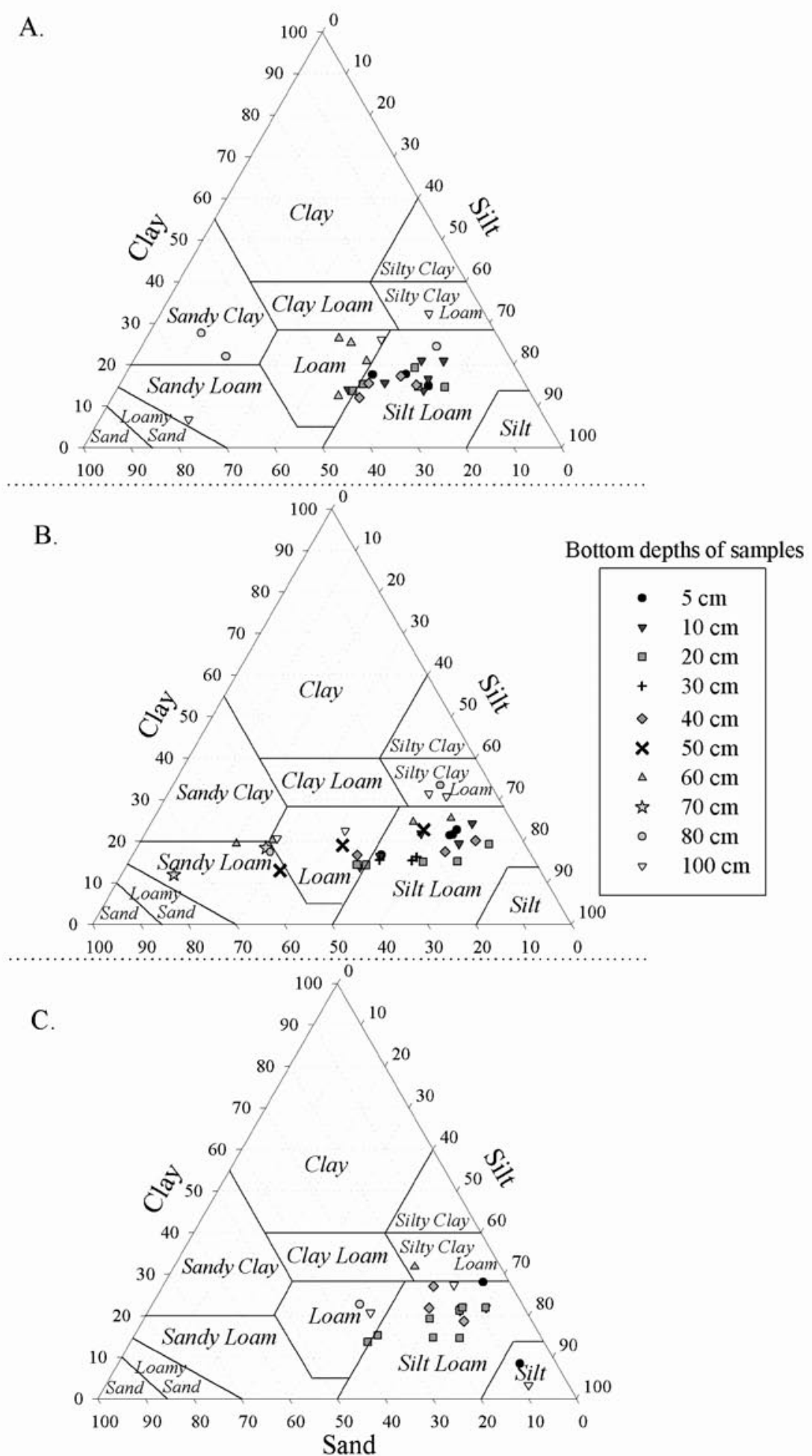

Figure 3. Soil particle size distribution by textural class for each community: A) restored prairie (RP); B) reed canary grass (RCG); and C) sedge meadow (SM). Depth classes of sampling intervals are indicated by different symbols. The median particle size was $0.0199 \mathrm{~mm}$ for the RP and $0.0122 \mathrm{~mm}$ for the SM, while particle distributions of the RCG soils appear to span both distribution fields, with a mean particle size of $0.0177 \mathrm{~mm}$. For particle distributions at depth intervals the silt and sand contents of the SM area were significantly different from both RP and RCG paired depths ( $p<0.003$ for both RP-SM and RCG-SM silts, $p<0.0002$ for RP-SM sands, $p<0.03$ for the RCG-SM sands).
Nitrogen pools are illustrated in Figure 5. Total nitrogen behaved similarly to total carbon (Figure 5A), with similar statistical significance. The soils from the RCG zone had a notable $\mathrm{NO}_{3}-\mathrm{N}$ increase at $20 \mathrm{~cm}$, nearly twice as much as in the SM. The carbon to nitrogen ratios of all the soils (Figure 6) were very similar in the upper $20 \mathrm{~cm}$, falling within the range of 13 to 15 . Below that depth, the ratios differed, with RCG and SM ratios varying most widely: the RCG ratio decreased significantly, while that for SM increased.

Bioavailable phosphorus (Figure 7) is most concentrated in the upper 40 $\mathrm{cm}$, corresponding with the total $\mathrm{C}$ and $\mathrm{N}$ values and suggesting that most $\mathrm{P}$ was in the organic form. High bioavailable phosphorus at depth was probably due to the presence of a clayenriched interface between the silty soils and the sandier outwash beneath the soil, which acted as an aquitard (impermeable layer), inhibiting nutrient-enriched sediments and soil water infiltration. We noted this clay layer in both the RP and RCG stand, but not in the SM, which may partially explain the different depth distribution of bioavailable phosphorus in the SM soils. Both the RCG and SM soils contained more bioavailable phosphorus in the upper $40 \mathrm{~cm}$ than did the $\mathrm{RP}$, probably due to enrichment by organic matter accumulation.

We evaluated five acid-extractable elements, representing both naturally occurring and human-mediated processes in soils (Figure 8). Aluminum and manganese primarily represent natural soil processes in this setting. We found no significant difference between aluminum distribution in the RP and RCG soils, although RCG had slightly larger concentrations overall (Figure 8A). Manganese (Figure 8B) is strongly influenced by soil hydrology, and it followed expected trends. Sodium, copper, and zinc potentially enrich soils from human activities related to construction and transportation. In all cases, the elemental concentrations at depth for all three 


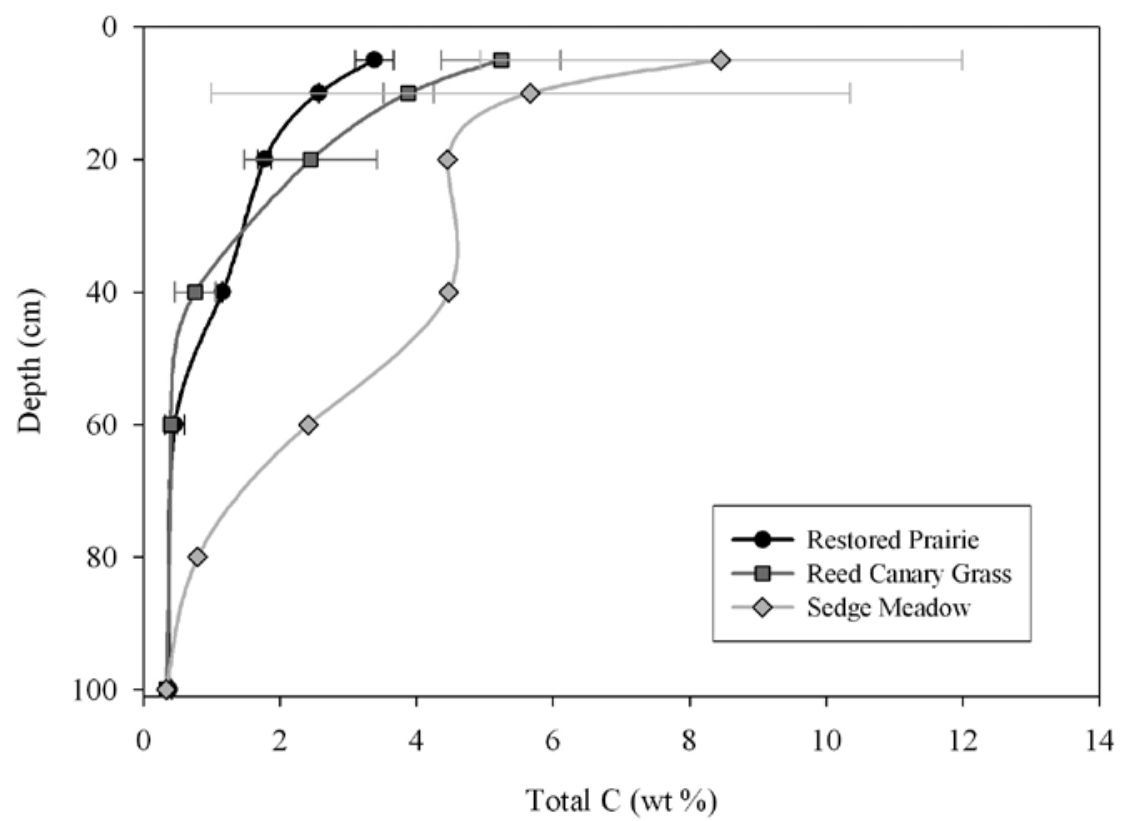

Figure 4. Total carbon depth distributions $( \pm 95 \% \mathrm{Cl})$ by community. No error bars indicate that only one sample was evaluated per depth class. Profile mean differences in $C$ content were significant only between restored prairie versus sedge meadow $(p<0.006)$ and reed canary grass versus sedge meadow $(p<0.005)$. communities are very similar, which indicates that parent material for the soils is essentially the same across the entire setting, confirming that the moist and wet prairie communities evolved from slight differences in topography and surface hydrology, and serving as an effective baseline for judging top-down effects.

Enrichment of sodium $(\mathrm{Na})$ can occur where roads are salted. In Curtis Prairie, we found the largest $\mathrm{Na}$ concentrations in the RCG soil, with the next largest concentrations in the SM (Figure 8C). The RP had the lowest concentrations, but they doubled with depth where $\mathrm{Na}$ encountered the clayenriched layer and soluble forms were sequestered.

Distribution of copper $(\mathrm{Cu})$ differed significantly between the RCG and SM soils (Figure $8 \mathrm{D}$ ). To the depth of $60 \mathrm{~cm}$, RCG and SM soils covaried in $\mathrm{Cu}$, suggesting that the element is being enriched by stormwater inflow events. Enrichment of $\mathrm{Cu}$ was
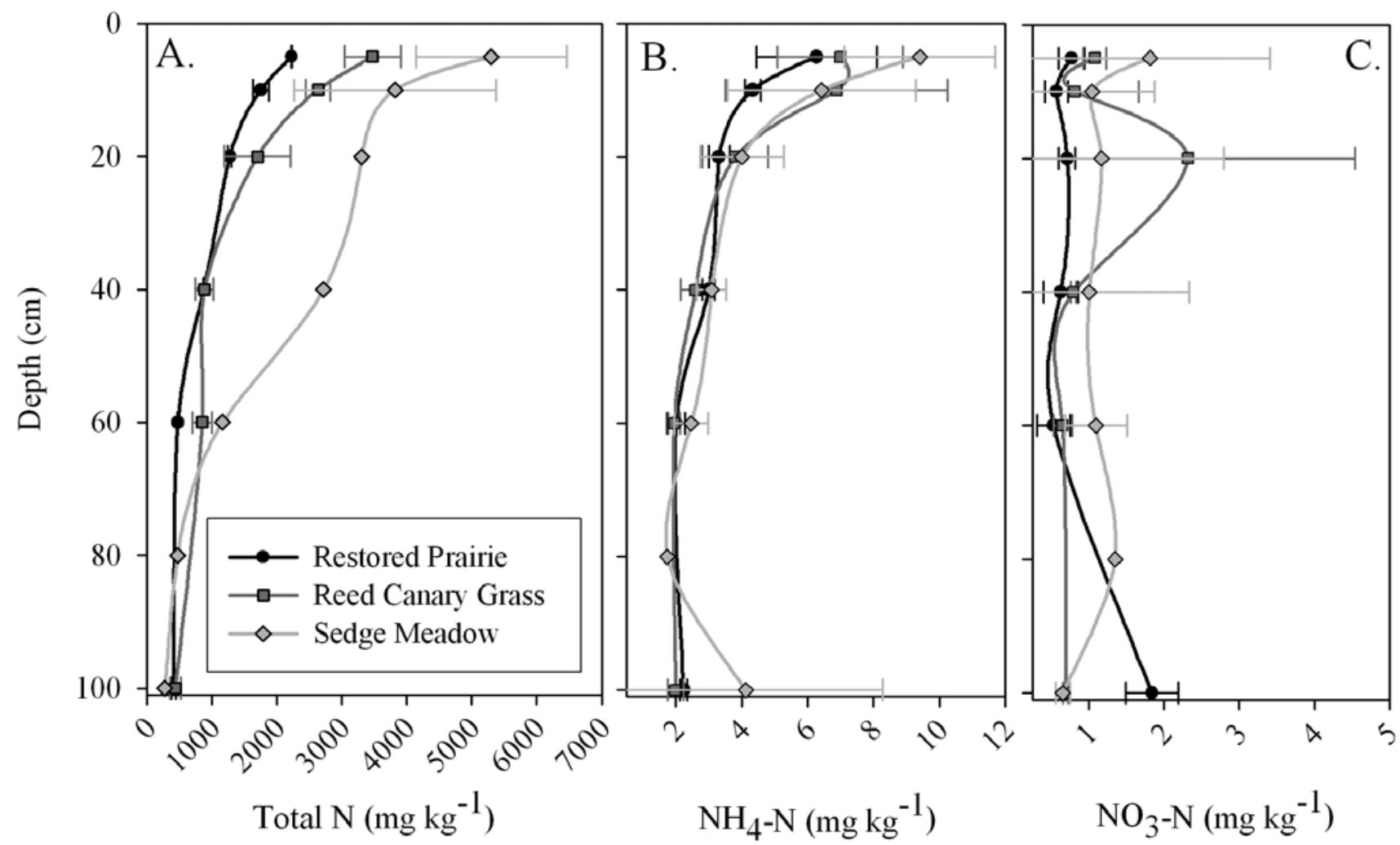

Figure 5. Nitrogen $(\mathrm{N})$ pool depth distributions ( $\pm 95 \% \mathrm{Cl})$ : A) total $\mathrm{N} ; \mathrm{B}$ ) ammonium-N; C) nitrate-N. No error bars indicate that only one sample was evaluated per depth class. There were no significant differences between communities in the depth distribution of $\mathrm{NH}_{4}-\mathrm{N}$, which was concentrated in the upper $20 \mathrm{~cm}$. Nitrate- $\mathrm{N}$ had covariant differences in depth distribution between the restored prairie (RP) and sedge meadow, which had slightly more $\mathrm{NO}_{3}-\mathrm{N}$ than the RP. 


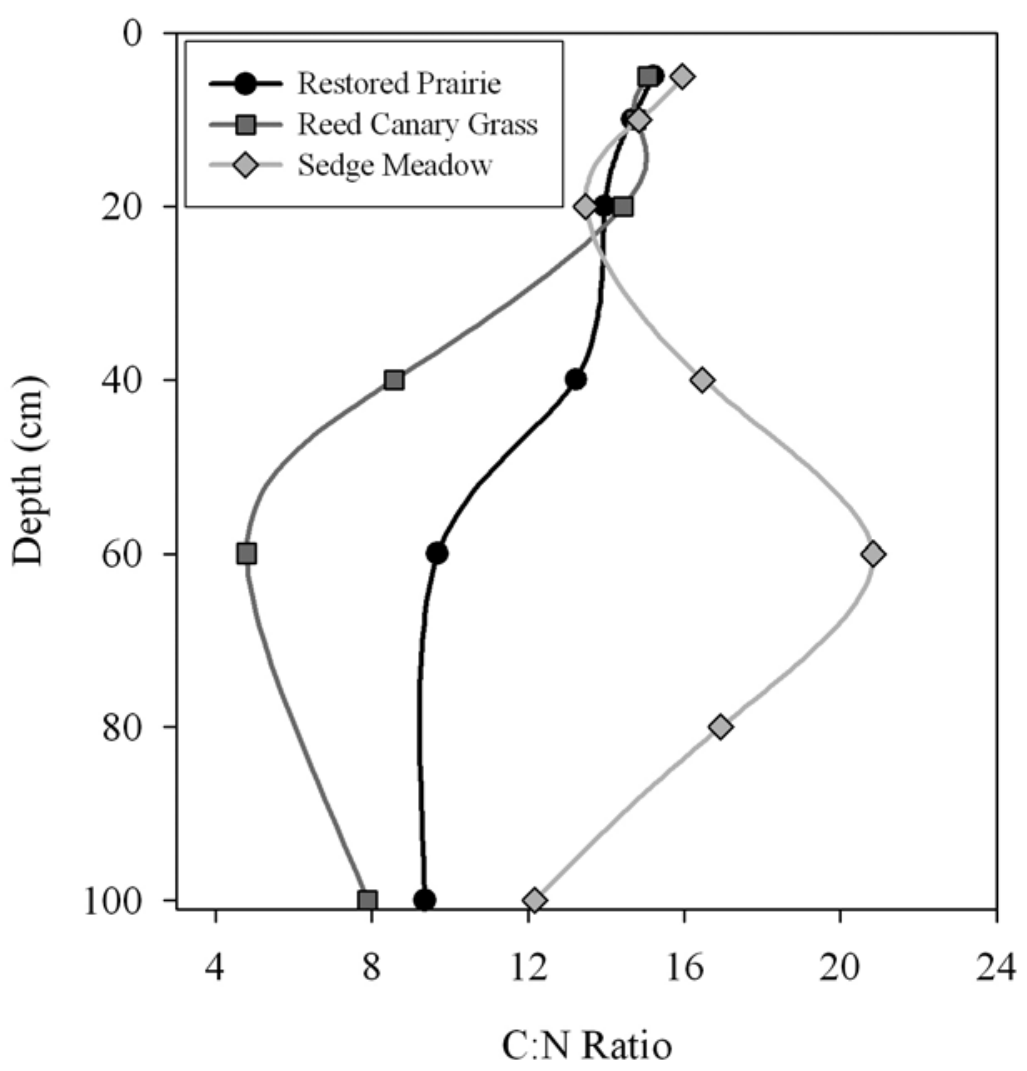

Figure 6. Generalized carbon to nitrogen ratios. The ratios were very similar in the upper $20 \mathrm{~cm}$, but differed below, with RCG and SM ratios varying most widely.

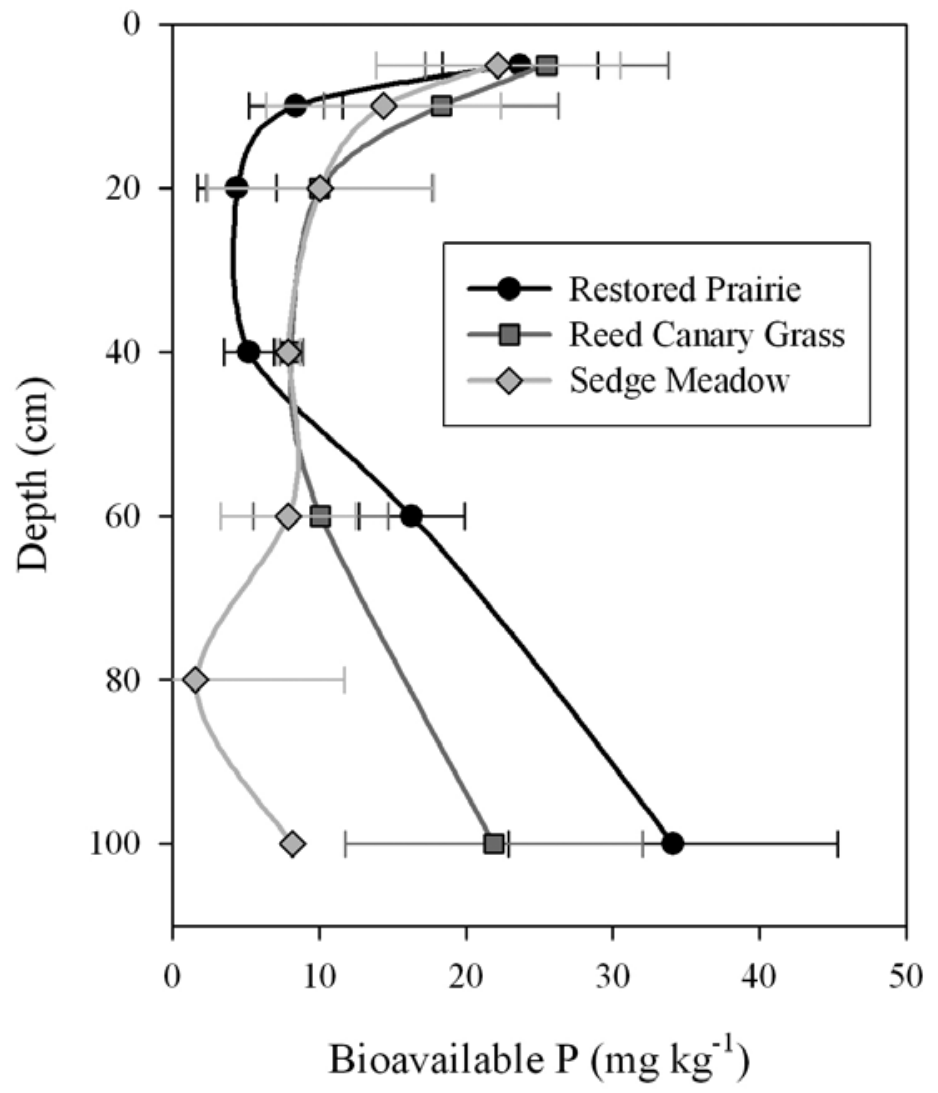

Figure 7. Bioavailable phosphorus (BAP) $( \pm 95 \% \mathrm{Cl})(p<0.006)$. not noted in higher elevation soils of the RP. Zinc ( $\mathrm{Zn})$ has accumulated significantly in the upper $20 \mathrm{~cm}$ of the RCG stand and in the upper 10 $\mathrm{cm}$ of the SM (Figure 8E). Zn has not accumulated in the RP, thus strengthening the hypothesis that stormwater has influenced the biogeochemistry of the sites.

\section{Discussion}

Our hydrology and soil data revealed a definite signature of urban stormwater influence in the RCG stand, indicated by nutrients and inorganic constituents, particularly the metals. The water table was at least $3 \mathrm{~m}$ below the land surface, which suggests that surface water inputs alone are controlling seasonal flooding and subsequent soil characteristics in central Curtis Prairie. This is especially the case during early spring, when rain or snowmelt water saturates the surface and frozen subsoil prevents infiltration. The stream that eroded after Curtis Pond began discharging stormwater skirts the southern edge of the RCG stand, following a slight break in slope in a topographic low. At this point, the gradient is insufficient to maintain streamflow and the stream overflows its banks. However, topography confines most stormwater to the RCG stand, so that the adjacent $\mathrm{RP}$ is not typically inundated.

The strongest evidence of human influence to the prairie is the distributions of $\mathrm{Cu}$ and $\mathrm{Zn}$ (Figures 8D and $8 \mathrm{E}$ ). These metals are released with automobile break pad wear and general metal corrosion (Burton and Pitt 2002) and are likely carried into Curtis Prairie along with stormwater. Because elevated $\mathrm{Cu}$ and $\mathrm{Zn}$ occur to depth in the RCG soil and in the surface of SM soil not yet invaded by RCG, these metals indicate stormwater influence and might predict future RCG expansion. Elevated Na concentrations (Figure 8C) in RCG soil are indicative of the probable influence of road salt from the bordering streets and freeways near the prairie. Potassium, another component of road salt 


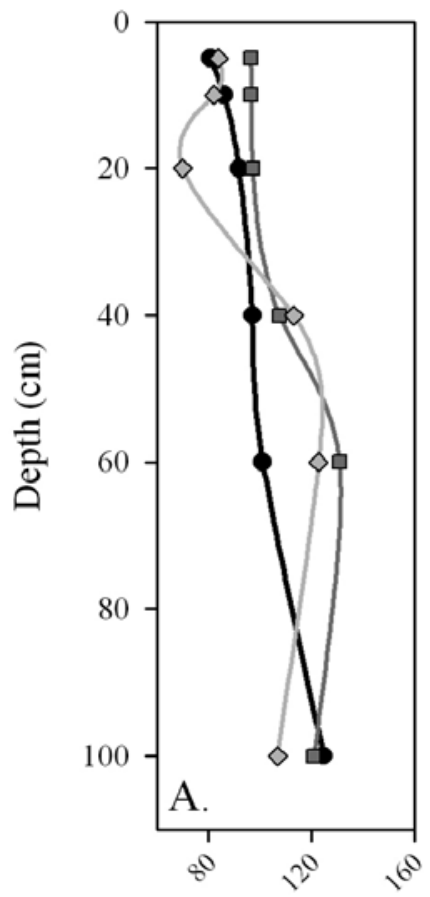

$\mathrm{Al}\left(\mathrm{mg} \mathrm{kg}^{-1}\right)$

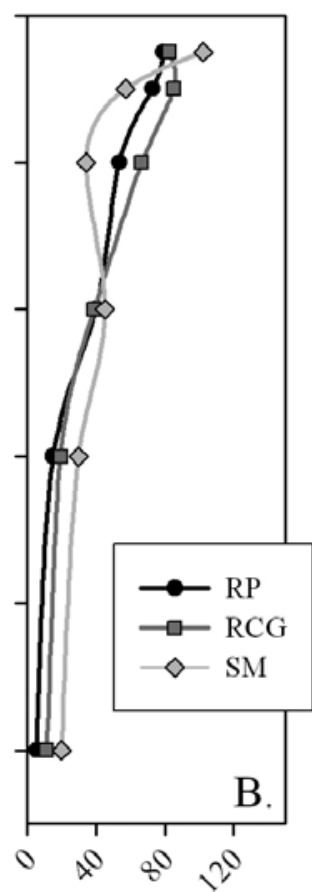

$\operatorname{Mn}\left(\mathrm{mg} \mathrm{kg}^{-1}\right)$

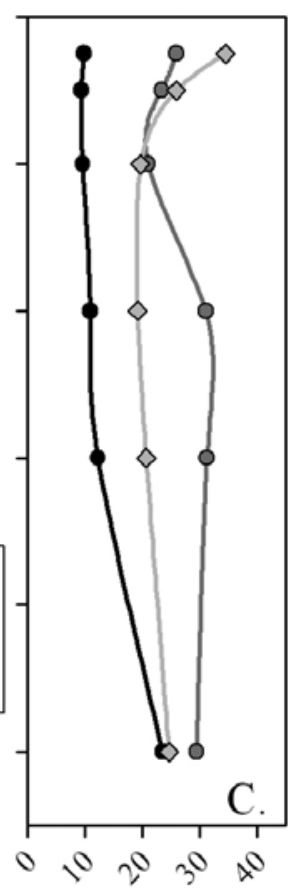

$\mathrm{Na}\left(\mathrm{mg} \mathrm{kg}^{-1}\right)$

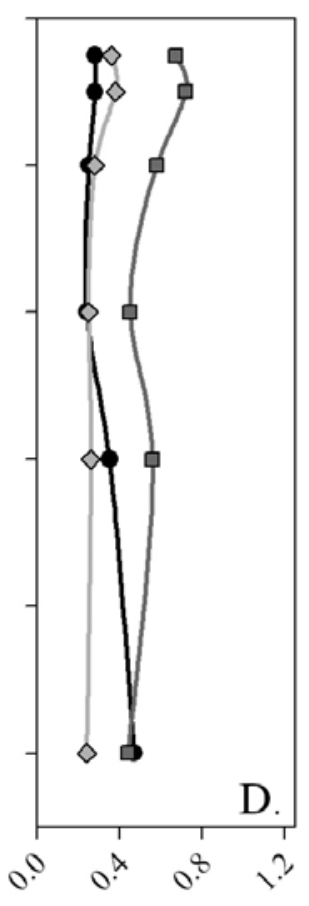

$\mathrm{Cu}\left(\mathrm{mg} \mathrm{kg}^{-1}\right)$

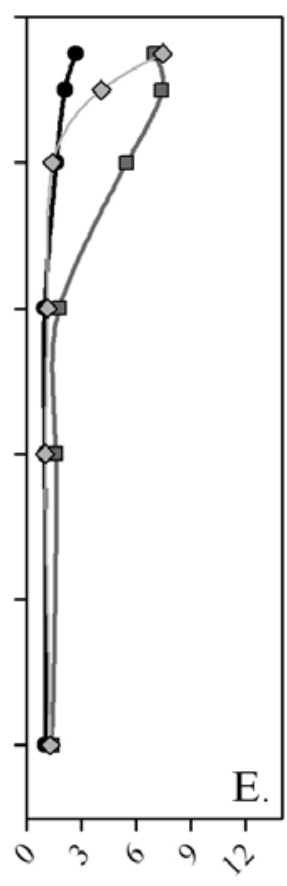

$\mathrm{Zn}\left(\mathrm{mg} \mathrm{kg}^{-1}\right)$

Figure 8. Extractable element contents-A) aluminum (Al); B) manganese (Mn); C) sodium ( $\mathrm{Na}$ ); D) copper (Cu); and E) zinc (Zn). The sedge meadow (SM) soils had less Al relative to the other settings in the upper $20 \mathrm{~cm}$, most likely due to dilution by organic matter; however, at depth, Al values in increased significantly to match the reed canary grass (RCG) values. Profile mean concentrations of Cu were significantly higher in RCG than restored prairie (RP) $(p<0.007)$, and Zn means in RP were significantly lower than RCG $(p<0.005)$ and SM $(p<0.007)$.

blends, is also elevated in the surfaces of the RCG and SM (Bemis, unpub. data). Sodium is an effective dispersing agent and can promote the loss of structure in the soil when it occurs in excess. The loss of structure also means a loss in infiltration capacity, as pores and fractures become filled with dispersed clays (Caron et al. 1992, Keren 2000). Linked to the observation that soil structure was weak to nonexistent in the RCG, the excess $\mathrm{Na}$ may have contributed to the poorly drained conditions that predispose this area to thriving RCG. Even a slight increase in $\mathrm{Na}$ in low-clay-content soils can strongly affect structural components, contributing to wetter surface conditions. RCG readily expands in direct response to flooding and indirectly where flooding damages native plants and creates canopy openings (Kercher et al. 2004).

Contrary to expectations, the RCG stand has not accumulated significant quantities of silt, which often acts to suppress native species not adapted to flooding conditions. RP and RCG soil did not differ in silt and sand, suggesting that silt accumulation alone is not a primary cause for the historical expansion of RCG beyond the stream bank. Silts were more prevalent in the SM, where it comprised $43-89 \%$ by weight (Figure 3). Thus, the mere presence of elevated silt in soils is not a sufficient predictor of RCG invasion and expansion.

The dynamics of some of the nutrient and organic contents indicate how changing edaphic conditions may favor the invasion of RCG into Curtis Prairie. Total C, N, and $\mathrm{NH}_{4}-\mathrm{N}$ values were similar for RP and RCG soils (Figures 4, 5A, 5B), suggesting similar prevailing processes regarding organic matter dynamics in the moist prairie. Soil processes in the SM zone were different, with organic matter preserved in the poorly drained areas. This contrasting response indicates different dynamics in SM compared to the RCG stand, despite the latter's episodic saturation by stormwater. A factor contributing to the total $\mathrm{C}$ pattern for the three communities may be the addition of mineral matter into the RCG stand through sedimentation. If, at one time, the RCG soil was similar to the present SM soil, then its total carbon levels would have been significantly higher than in the surrounding RP.

Additional nutrient-related behavior of RCG is indicated in the $\mathrm{NO}_{3}-\mathrm{N}$ and bioavailable phosphorus levels in the three communities (Figures 5C and 7). In this case, RCG and RP soils had similar $\mathrm{NO}_{3}-\mathrm{N}$ content, except for a notable increase at $20-\mathrm{cm}$ depth in all profiles grouped to yield the mean values at the time of the sampling (late autumn). The elevated $\mathrm{NO}_{3}-\mathrm{N}$ content was 5 times the RP level and 2.5 times the SM level at this same depth. Nitrate- $\mathrm{N}$ is very soluble; the nutrient can easily flow in from residential areas with over-fertilized lawns, and has been found to catalyze RCG invasion (Green and Galatowitsch 2002, Kercher et al. 2007). It is also 
possible that RCG had an influence in accumulating nitrogen that enhanced soil nutrient levels upon decomposition (Herr-Turoff and Zedler 2005). In contrast to $\mathrm{NO}_{3}-\mathrm{N}$, bioavailable phosphorus was high in both the RCG and SM (Figure 7), probably due to stormwater transport of P-enriched sediments from surrounding residential areas. Thus, either nutrient enrichment influenced the distribution of RCG or RCG influenced the retention of $\mathrm{N}$ and $\mathrm{P}$.

\section{Conclusions}

Several trends in soil and hydrologic conditions favor the growth of RCG in the midst of a thriving restored prairie. These differences arise from the influence of stormwater discharged from Curtis Pond. Biogeochemical properties were the most telling evidence of this environmental influence. High levels of total $\mathrm{C}$ and $\mathrm{N}$ in the SM soils were expected due to poor drainage, with significant accumulations extending below $40 \mathrm{~cm}$, where the buried surface occurred. In contrast, both RP and RCG had $\mathrm{C}$ and $\mathrm{N}$ forms concentrated exclusively in surface soil. Elevated nutrients in soils downstream of Curtis Pond indicate increased influx from stormwater or increased retention by RCG. Regardless of the cause and effect, this alteration likely favors the sustained growth of RCG. Finally, elevated $\mathrm{Na}$ and metal concentrations in the surface and shallow subsurface portions of the soils in the RCG and SM demonstrate that urban run-off has affected Curtis Prairie.

We expected to find buried organic surface horizons in the RCG stand, but only found them in the SM, approximately $200 \mathrm{~m}$ downstream from the Curtis pond discharge. Textural characteristics of the soils differed little among the three communities, rendering this diagnostic tool less useful than anticipated.

Our reconstruction of how RCG invaded Curtis Prairie is that soils along the stormwater outflow were initially scalped of their top soil. Next, down-cutting created a stream channel and exposed a bare bank where RCG seedlings established in the highlight environment. Simultaneously, fine-grained (silty) nutrient- and saltenriched sediments were deposited on the stormwater flood plain. Sodium degraded soil structure, compromised infiltration capacity, and enhanced surficial flooding. Ponding subdued many native prairie plants and created canopy gaps favoring RCG. RCG expanded to encompass the elevations subject to intermittent flooding.

We predict that RCG will not expand upslope due to topographic constraints, but it may continue to expand into the SM, given continued inflows of charged sediments and surface water. Thus, invisible but detrimental constituents of stormwater should be assessed and contained to reduce threats to the SM and make restoration of the RCG stand more feasible.

\section{Acknowledgments}

This study was funded by an Arboretum Research Assistantship to B. Bemis and funds for soil analysis to C. Stiles. We thank Kevin McSweeney for advice, Mike Healy for digital mapping, Ben Montgomery, Pete Wakeman, Phil Speth, Mark Krupinski and David Zaber for assistance with coring and well installation.

\section{References}

Blewett, T.J. and G. Cottam. 1984. History of the Wisconsin Arboretum prairies. Transactions of the Wisconsin Academy of Sciences, Arts and Letters 72:130-144.

Bray, R.H. and L.T. Kurtz. 1945. Determination of total, organic, and available forms of phosphorus in soils. Soil Science 59:39-45.

Burton, G.A., Jr., and R.E. Pitt. 2002. Stormwater Effects Handbook: A Toolbox for Watershed Managers, Scientists, and Engineers. Boca Raton, FL: CRC Press.

Caron, J., B.D. Kay, J.A. Stone and R.G. Kachinoski. 1992. Modeling temporal changes in structural stability of a clay loam soil. Soil Science Society of America Journal 56:1597-1604.

Caron, J., C.R. Espindola and D.A. Angers. 1996. Soil structural stability during rapid wetting: Influence of land use on some aggregate properties. Soil Science Society of America Journal 60:901-908.

Cochrane, T., K. Elliot and C. S. Lipke. 2006. Prairie Plants of the University of Wisconsin-Madison Arboretum. Madison: University of Wisconsin Press.

Curtis, J.T. 1951. Arboretum master development plan: I-The Prairie. Unpublished manuscript, University of Wisconsin-Madison Arboretum.

Galatowitsch, S.M, N.O. Anderson and P.D. Ascher. 1999. Invasiveness in wetland plants in temperate North America. Wetlands 19:733-755.

Gee, G.W. and J.W. Bauder. 1996. Particle size analysis. Pages 383-411 in A. Klute (ed), Methods of Soil Analysis: Pt.1. Physical and Mineralogical Methods, 2nd ed. Madison, WI: Soil Science Society of America.

Green, E.K. and S.M. Galatowisch. 2002. Effects of Phalaris arundinacea and nitrate- $\mathrm{N}$ addition on the establishment of wetland plant communities. Journal of Applied Ecology 39:134-144.

Herr-Turoff, A. and J.B. Zedler. 2005. Does wet prairie vegetation retain more nitrogen with or without Phalaris invasion. Plant and Soil 277:19-34.

Hole, F.D. 1976. Soils of Wisconsin. Madison: University of Wisconsin Press. http://digital.library.wisc.edu/1711.dl/ EcoNatRes.Hole01.

Kercher, S.M., Q.J. Carpenter and J.B. Zedler. 2004. Interrelationships of hydrologic disturbance, reed canary grass (Phalaris arundinacea L.), and native plants in Wisconsin wetlands. Natural Areas Journal 24:316-325.

Kercher, S.M., A. Herr-Turoff and J.B. Zedler. 2007. Understanding invasion as a process: The case of Phalaris arundinacea in wet prairies. Biological Invasions 9:657-665.

Keren, R. 2000. Salinity. Pages G3-G25 in M.E. Sumner (ed), Handbook of Soil Science. Boca Raton, FL: CRC Press.

Lavergne, S. and J. Molofsky. 2004. Reed canary grass (Phalaris arundinacea) as a biological model in the study of plant invasions. Critical Reviews in Plant Sciences 23:415-429.

Lindig-Cisneros, R. and J.B Zedler. 2002a. Phalaris arundinacea seedling establishment: Effects of canopy complexity in fen, mesocosm, and restoration experiments. Canadian Journal of Botany 80:617-624.

Lindig-Cisneros, R. and J.B. Zedler. 2002b. Relationships between canopy complexity and germination microsites 
for Phalaris arundinacea (L.) Oecologia 133:159-167.

Mack, R.N., D. Simberloff, W.M. Lonsdale, H. Evans, M. Clout and A.F. Bazzaz. 2000. Biotic invasions: Causes, epidemiology, global consequences, and control. Ecological Applications 10:689-710.

Maurer, D.A. and J.B. Zedler. 2002. Differential invasion of a wetland grass explained by tests of nutrients and light availability on establishment and clonal growth. Oecologia 131:279-288.

Miller, R.C. and J.B. Zedler. 2003. Responses of native and invasive wetland plants to hydroperiod and water depth. Plant Ecology 167:57-69.

Morrison, S.L. and J. Molofsky. 1998. Effects of genotypes, soil moisture, and competition on the growth of an invasive grass Phalaris arundinacea (reed canary grass). Canadian Journal of Botany 76:1939-1946.

Nelson D.W. and L.E. Sommers. 1996. Total carbon, organic carbon, and organic matter. Pages 961-1010 in D.L. Sparks (ed), Methods of Soil Analysis: Pt. 3. Chemical Methods. Madison, WI: American Society of Agronomy.

Olson, S. R. and L.E. Sommers. 1982. Phosphorus. Pages 403-430 in A.L. Page, R.H. Miller and D.R. Keeney (eds), Methods of Soil Analysis: Part 2.
Chemical and Microbiological Properties, 2nd ed. Madison, WI: American Society of Agronomy.

Sachse, N.D. 1974. A Thousand Ages, revised ed. Madison: University of WisconsinMadison Arboretum.

Sanders, L.L. 1998. Soil water and ground water. Pages 91-131 in L.L. Sanders (ed), A Manual of Field Hydrogeology. Upper Saddle River, NJ: PrenticeHall.

Schoeneberger, P.J., D.A. Wysocki, E.C. Benham and W.D. Broderson. 2002. Field Book for Describing and Sampling Soils, version 2.0. Lincoln, NE: National Soil Survey Center.

Snyder, T.A., III. 2004. A spatial analysis of grassland species richness in Curtis Prairie. M.S. thesis, University of Wisconsin-Madison.

Thomas, G.W. 1996. Soil pH and acidity. Pages 475-490 in D.L. Sparks (ed), Methods of Soil Analysis: Pt. 3. Chemical Methods. Madison, WI: American Society of Agronomy.

United States Geological Survey (USGS). 1975. Hydrology of the Lake Wingra Basin, Dane County, Wisconsin. Madison: USGS in cooperation with the University of Wisconsin-Geological and Natural History Survey.

Wisconsin State Climatology Office (WISCO). 2007. Arboretum University of Wisconsin (470273). http://www. aos.wisc.edu/\%7Esco/clim-history/ stations/470273.html.

Yeomans, J.C. and J.M. Bremner. 1991. Carbon and nitrogen analysis of soils by automated combustion techniques. Communications in Soil and Plant Analysis 22:843-850.

Zedler, J.B. and S. Kercher. 2004. Causes and consequences of invasive plants in wetlands: Opportunities, opportunists, and outcomes. Critical Reviews in Plant Sciences 23:431-452.

Cynthia A. Stiles, Supervisory Soil

Scientist, USDA-NRCS, National Soil

Survey Lab, Mail Stop 41, 100 Centennial Mall, Lincoln, NE 68508-3866, 402/437-4007,cynthia.stiles@lin. usda.gov

Brynn Bemis, The Nelson Institute of Environmental Studies, 550 North Park St, Madison, WI 53706-1491

Joy Zedler, Department of Botany and UW-Arboretum, 430 Lincoln Dr, Madison, WI 53706-1313; and 1207 Seminole Hwy, Madison, WI 53711 